\title{
Ėjìgbòmekùn Market in llé-Ifẹ̀: Investigating the Nexus between the Mythical and Modern era of the Yorùbá History
}

\author{
Abiodun Ajayi and Olusegun Rotimi Faturoti \\ Adeyemi College of Education, Ondo, Nigeria \\ biodunajayi1@gmail.com \\ fattseg60@gmail.com
}

\begin{abstract}
E’jìgbòmẹkùn market has featured prominently in Yorùbá folklore, Ifá verses, maxims, and proverbs. Therefore, the presence of a market by that name in the modern time at the northern end of İlàrẹ street in Ilé-Ifẹ̀ reminds one of that mythical Ejigbomenkun market and the mysteries that surrounded it. One of the questions that normally flow into one's mind is whether or not the modern Ejigbomekun market is also shrouded in such mysteries as attributable to the mythical one. This study aims at ascertaining the importance of Ejjigbòmekùn market in the Yorùbá history as references are usually made to it by the entire Yorùbá race as an important institution. The study also aims at investigating the link between the mythical and the modern Ejigbomẹun markets with the use of historical method which involves the use of oral data gathered through interviews, archival documents, and relevant texts. It is hoped that historicizing such an institution with a mythical existence that have a modern offshoot will engender a better understanding of the Yorùbá history.
\end{abstract}

\section{Introduction}

While farming remained the dominant occupation before the advent of the colonial administration in Yorùbáland, markets provided the lucrative outlets for the trading of the farm produce. Thus, market had been a vital part of the Yorùbá life as it was a lubricant that oiled the wheels of the people's economy 
and the associated traditional system. The nature of the Yorùbá market is in line with Oluwole's definition of market as "a place where transactions for the exchange of goods and services take place." This definition was corroborated by Olupe, when he defined market as "an institutional arrangement that brings buyers and sellers into a close contact." 2 In the words of Akinwande, of the three prominent places where the Yorùbá people mingle, such as social events, town hall meetings, and markets, market takes the lead. ${ }^{3}$ All of these combine to underpin the fundamentals of mutual co-existence among the Yorùbá vividly, particularly with regards to market which has been found out to be an important part of their life.

In line with Yorùbá traditional lore, market is not an accidental institution. This is because, before a market could be established, it had to be at the discretion of the king, who in turn would engage the services of the diviners for consultation with Ifá oracle in order to determine the location of the proposed market and its period. ${ }^{4}$ In most Yorùbá communities, markets are usually located in front of the king's palaces, which were usually the center of the town. Such markets were aptly titled Ojja Ọba (The king's market). In IléIfẹ̀ for instance, Oja Oba is located at a stone throw to the king's palace. ${ }^{5}$ The market is given other appellations like, Ọjà Ifẹ̀ (Ifẹ̀ market), Oja Ajé (Ajés market), Ọjà Ėjìgbòmẹkun (E’jìgbòmẹkùn market), Ojà Ìlú (town's market) and most remarkably Ọjà Ộrúnmi là (Ộrúnmi la’s market). ${ }^{6}$

Ejjigbomẹkun market exhibits all the features of Yorùbá market. All these features that are attributable to Yoruba traditional markets are indicative of the roles they play. The siting of Ejigbomẹkun market in the neighborhood of the king's palace gave the king the opportunity to maintain effective control on market proceedings through his representation by the queens and palace envoys. This is because, the king was forbidden by tradition and custom to attend market sessions himself. The reason for this location was to ensure security of the market, since the king enjoyed unparalleled guard by powerful men, reputable hunters, and the magical personalities. ${ }^{7}$ This portends

1 T. Oluwole. (2017), "Markets, Marketing and Advertisement," in Toyin Falola and Akintunde, Akinyemi (eds.), Culture and Customs of the Yorùbá. Austin: Pan African University Press, p. 553.

2 D. Olupe. (2017), Cultural Practices of the Yorùbá. Lagos: Rilfax Books, p. 82.

3 Oral interview with Chief Akinwande Olajire, the Baba oja of Ejigbomekun market, 65 years, 12/10/2019.

4 Ibid.

5 D. Ogunremi. (1998), "Foundation of the Yoruba Economy in the pre-Colonial era" in Deji Ogunremi and Biodun Adediran (eds.), Culture and Society in Yorubaland, Ibadan: Rex Charles Publication, p. 120.

6 Oral interview with Chief Akinwande Olajire, the Baba-Oja.

7 D. Ogunremi. (1998), "Foundation of the Yoruba Economy, p. 120. 
assurance of adequate protection for the attendants of the market, and they paid for this inform of tributes and tolls to the king's agents in the market.

E’jìgbòmẹkun, like every other Yorùbá traditional markets, also served as a rendezvous for various social activities. Such activities include celebration of festivals, performance of public rituals that have to do with the peace and prosperity of the community among others. ${ }^{8}$ For example, from the time immemorial, the Ajé Shrine (ojúbọ ajé) was located in Ėjìgbòmẹùn market. Ajé is a Yorùbá goddess of wealth. The import of the shrine in the market is that, there is an intimate relationship between money and market, hence the saying:

Ajé ló bi Ojà

Ojà ló bí Ajé

A dífáfún Èji wọ̀wò

Tó lóun ó lọ ná oja láimówó lộwọ́

A ki íperí ojà lái lówó lộwọ́ o

Ejiwộwọ má re ọjà láimówó lộộ o

Ko o má baá gbọnwọ́ popo lábọ ọjà. ${ }^{9}$

The goddess of money begat market

Market begat the goddess of money

Divine for Ejjìọ̀wọ̀

Who was going to the market without money

No one discusses the issue of market without money

Ejì wọ̀wọ̀ do not go to the market if you don't have money

Lest you come back empty handed

Similar cases were also observed by Mabogunje and Omer-Cooper in Kuta, where the chief goes to Mosun market to dance on the second day of Alugbua festival, and this ends the official part of the festival. ${ }^{10}$ As the market served as the sources of such ritual materials, so were they consummated right there in the market with the king and priest officiating. ${ }^{11}$

An important feature of Ejigbomẹkun market was its serving as a medium of disseminating information. For instance, in the evening of Edi, Aje and

8 M. K. Mcintosh. (2009), Yoruba Women, Work, and Social Change, Indiana: Indiana University Press. p. 66.

9 Oral interview with Chief Akinwande Olajire, ibid.

10 A.L. Mabogunje and J. Omer-Cooper. (1971), Owu in Yoruba History, Ibadan: Ibadan University press. p. 108.

11 O.B. Olaoba. (2000), Bodija Market in Ibadan 1987-1995, Ibadan: John Archers Publishers, p.11. 
Olojo festivals in Ile-Ife, palace officials are expected to visit Ėjìgbòmẹkùn market to make announcements and to collect sacrificial items in the same way as it happened in Osogbo, during wiwa Osun, a ceremony in preparation for Osun festival in Osogbo. ${ }^{12}$ During this time, the Ataoja and the Iya Osun visit the market to declare publicly that it is time "to eat new yam" and thus remove the taboo forbidding the harvesting and selling of new yams at the king's market (oja oba) in Osogbo. ${ }^{13}$ Official announcement of Ogun festival in Ondo is also done in the market, nine days to the festival. ${ }^{14}$

Although there was a specialized medium for this, decisions, policies and programs of development had better hearing during market sessions, because attendants would take the information home for the benefit of other members of their families. ${ }^{15}$ Ejigbomẹkun market was also a place for entertainers, a hideout for criminals, debtors, etc. Other people that could also be found in its sessions included, beggars, and love makers, friends, and relations who came to meet for settling quarrels, make deals, and exchange views. medicinal herbalists, religious proselytisers, diviners, and so on also attended markets to win new converts and sell their products and services. Equally, political matters, discovery of new ailments, of new techniques and of new crops were made known in the markets. ${ }^{16}$ Markets were places where celebrants of important occasions brought their entourage and drummers. ${ }^{17}$

On the other hand, Ejigbomẹun market is always closed during religious or cultural confinements or ceremonies. An important example is during Edi festival, when Tele will carry ritual items to Moremi Forest (Igbo Moremi) in the company of other spiritual officials of the king. On their way from the Moremi Forest, Eri, a priestess of the goddess Moremi will hold an antelope lap (tete e tu) which she would hand over to the first person she met on her way. The victim here dares not reject it. As soon as a person was on sight and was targeted by the Moremi Priestess, the individual will not be able to run, as certain spiritual forces would have held him down. The implication of this is that, the person will not live to witness another year. ${ }^{18}$ The Oro and

12 Oral interview with Chief Akinwande Olajire; ibid.

13 M. Joseph Murphy and Mei-Mei Sanford. (2001), Osun Across the Waters: A Yoruba Goddess in Africa and Americas. Bloomington, Indiana: Indiana University Press. p. 54.

14 J.K. Olupona. (1991), Kingship, Religion, and Rituals in a Nigerian Community: A Phenomenological Study of Ondo Yoruba Festivals. Stockholm, Almqvist and Wiksell International (Stockholm Studies in Comparative Religion, No 28, p.119.

15 P. O. Sada and M.L. McNulty, "Traditional Market in Lagos: A Study of the Changing Administrative Processeses and Marketing Transactions ", in Quarterly Journal of Administration, Vol. 8, No. 2 (1974). pp. 149-165.

16 . D. Ogunremi. (1998), "Foundation of the Yoruba Economy... p.121.

17 M. K. Mcintosh. (2009), Yoruba Women, Work, and Social Changes. p. 66.

18 Oral interview with Chief Akinwande Olajire, ibid. 
Egungun cults do not imposed curfews in Ile-Ife as in some parts of Yorubaland, but Ejigbomẹkun market witness closures on the actual day of Olojo festival during which the king comes to the market to pray at the shrine of Aje goddess. The importance attached to this is inherent in an Ife adage, olojo $n$ laa fojo fun (the day is better given to its owner). Ejigbomẹkun market is also closed during Aje and Itapa festivals. ${ }^{19}$ Various other Yoruba traditional markets also witnessed total closure on festive occasions. For example, markets in Ibadan are usually closed for a day or two during the annual festival of Oke Ibadan..$^{20}$ Likewise, in Oyo and Ondo towns, markets are expected to be closed for a day, during annual festivals of Oro and Moko respectively. ${ }^{21}$

As in many Yoruba markets, several trees that are regarded as habitual residence of certain spirits or gods were planted in Ejjigbomẹkun market. For example, the shrine of Aje goddess used to be under one of the trees in the market in the same way as the feet of akoko, peregun and iyeye are shrines where Ogun is usually worshiped in many Yoruba traditional markets. ${ }^{22}$ In the modern time, Ejigbomẹkun has transformed into a market of lock up shops and Aje shrine has also become a fettered building as opposed to the age long foot of a tree. Many of the trees in the market were removed upon the complaint of the occupants of the newly built shops, that the roots of the trees were affecting the foundation of the buildings in the market. Many of the trees were also removed to create spaces for more shops. However, some trees are still being preserved in the market. On the contrary, the present king of Ife, who was responsible for putting up a modern building for Aje goddess recently gave a directive to the custodians of other gods to ensure adequate preservation of the trees in the shrines at their disposal. ${ }^{23}$

In the ancient time, Ejigbomẹkun market was accorded the greatest recognition and importance among other markets in Yorubaland. This is because, it was believed to be the oldest market in Ilé-Ifẹ̀ and the entire Yoru báland. According to Chief Akinwande, Ëjìgbòmẹkùn market is as old as Ilé-Ifẹ̀ itself. Although its exact date of establishment is not known, but it is speculated to be during the reign of Ọba Ộsẹanderuku, the ninth Oọ̀ni of Ifẹ.. ${ }^{24}$ According to oral traditions, Ejigbomẹkun market was also known as the O'rúnmi la's

19 Oral interview with Mrs. Toibat Omisore, a seller in the market, 88 years old, $8 / 2 / 2020$.

20 M. K. Mcintosh, 2009, Yoruba Women, Work, and Social Change...p. 66.

21 J.K. Olupona, Kingship, 1992, Religion, and Rituals in a Nigerian Community: ... p. 62 .

22 E.B. Idowu, 1975, Olodumare: God in Yoruba Belief, Great Britain: Campton Printing Press. p. 126.

23 Oral interview with Chief Akinwande.

24 Ibid. 
Market because immediately after its establishment, Òrúnmi là was always sighted at the market square to purchase most of his ritual items. Therefore, it was Ộnumi la's versatility in Ifá divination which resulted in his frequent attendance of the market to buy sacrificial items that made him the best customer to most sellers in the market. This resulted into a saying that, O'rúnmi là wá șẹ mí lộwọ kín rí tajés șe lónì-ín (Òrúnmì là, kindly come and be my first buyer so I can sell very well today). This was how Ejigbòmẹùn market assumed the alternative name, Ộrúnmi là's Market. ${ }^{25}$

\section{The Origin and Nature of Èjìgbòmekùn Market}

Èjigbomẹkù was believed to be the first market in Ilé-Ifẹ and Yorùbáland in general. According to Ife oral tradition, when Ò̀ranfẹ and Ajé descended from heaven, they looked around the world for a good place to settle and IléIfẹ̀ was the place of their eventual destination. The place they settled eventually became known as Ejigbomẹkun market. People all over the world came to them to buy and sell. As time went on, many other people came to join them as sellers in the market, thereby making the market to expand. ${ }^{26}$ The first set of people to sell things in the market were the lékulé ja and eléwe-ọmo (sellers of ritual items). Thus, the location became a market for Ifá priests and it became known as Oja Ò́rúnmi là as mentioned earlier. Many Ifá literary corpuses report of how O'runmi la visited the market on regular basis. It was the first place where cowry shells were used as means of exchange. This is because, the shell is the Aje's symbol of honor. According to Ife oral tradition, Ajé, Ộràmfẹ̀, and Ọṣun were friends and founders of Ẻjìgbòmẹkùn market. Osun would come from İta-Ọsṣun to join Ajé and Ộramfẹ̀ in the market. ${ }^{27}$

In Ejigbomẹkù market, commercial transactions spanned through day and night. The day session was called Ojàtayé (Earth market) and the midnight, Ojatoru (dark market). In the day, the market was meant for the humans. Many people come to buy and sell their goods and services while the mid-night session, according to oral traditional, was meant for the animals, demons and the dead. The tradition claims that during the mid-night session, sellers put on lantern (Ogựộ/Ộnàn). There is the effigy of Oșu Ejio deity (made of diamond) in the market. At day break, it shined in the market to announce the arrival of a new day. This ascribed the name Ifẹ Oodáyé, ibi ojúmọ́ rere tií mọ́ wálé ayé (Ifẹ̀, the dawn, where sun rises and lightens the

25 Ibid.

26 Ibid.

27 Ibid. 
world). This is because, the people believed Oșu Ejio' is the sun that rise to light up the whole world. ${ }^{28}$

Buying and selling activities that the market is all about is what the Yorùbá people eventually tagged Ajé. Since Ejìgòmẹkun market, the first market in the entire Yorùbáland is related to Ajé, so all other Yorùbá markets are closely related to Ajé. Ajé and market are inseparable. ${ }^{29}$

\section{The Èjìgbòmekùn Market in the Primordial and Present times-The difference}

As it was for other Yorùbá traditional markets, Ėjigbòmẹkù market in Ilé-Ifẹ̀ was an open space. Hence, merchandise were displayed in the open on bare ground, in containers or on make-shift tables and counters. Sometimes, temporary sheds made of palm fronds or fairly-used clothes were erected to cushion the heat of the sun. However, the narratives had changed today as lock-up shops are the order of the day. The practice becomes necessary in order to prevent theft, a cankerworm that has marked a departure from the old practice when after each market day, goods are covered and left until the next market day. The market has many officials, they include the Bàbálọjà, Deputy Bàbálọjà, Iyaloja, Deputy Iyaloja, Iyalaje, Deputy Iyalaje, and various other officials that make up the market council. ${ }^{30}$

In the past, Ejigbo'mẹun market was a five days market (oja orun), and the palace guards (Ẹmẹsẹ Ọba) used to visit Èjigbòmẹku'n market on daily basis to collect all kinds of foodstuffs for their feeding. This they did, of course, with the king's consent. Today, this practice is no longer in practice. Also, in the past, selected aides of the king of Ife was in the practice of visiting E'jigbomẹkun market to collect market fees (owo ojà). The fees were meant for the maintenance of the king's palace. This practice too had been stopped as the local council under which the jurisdiction the market falls is now directly involved in the collection of the market dues, being a major source of its internally generated revenue. ${ }^{31}$ The market day has now been fixed to honor the Aje goddess. Thus, it is now a Monday market (ojó ajé) of eight days. ${ }^{32}$

In the present day Ėjigbòmẹu'n Market, the age-old Ajé Shrine is still standing tall even though there has been a little shift from its original location. This was done to pave way for its edification as a big temple has been made to replace an uncovered shrine by the present king of Ife. It is on record

28 Oral interview with Chief Olajide Osuolale, the Deputy Babaloja Ejigbomekun market, 60 years, 12/10/2019, he was the head of the Lekuleja sellers in the market.

29 Ibid.

30 Oral interview with Mrs. Toibat Omisore.

31 Oral interview with Chief Olajide Osuolale, deputy Babaloja...

32 Oral interview with Mrs. Toibat Omisore... 
that, the king is always present whenever the Ajé festival has to be celebrated in the newly constructed shrine. This usually takes place in the month of March amid pomp and pageantry. This implies that the strong bond between Ajé goddess and market cannot be over-emphasized and that the king, being the political and religious head still plays prominent roles in the economic and religious development of the ancient town. ${ }^{33}$

\section{Misconceptions about Èjìgbòmẹùn Market}

Possibly, lack of adequate knowledge and its associated poor documentation has resulted into some misconceptions about Ėjigbomẹun Market. This is not unconnected with the relatedness of their names, such that, on hearing the name of the market, one's thought goes to the Yoruba town of Ejigbo, especially when such a person has never visited Ilé-Ifẹ̀ or Ėjìgbòmẹkü Market. For instance, Ejjigbòmẹkun Market has been erroneously associated with Ejigho town in Ọsun State. While explaining difficult words in Ifa verses, Ayo Salami described Ejigbomekun as an ancient city in the Yoruba enclave known for its thriving market. ${ }^{34}$ This is misleading, since there is no reference to Ile-Ife in the description. Wande Abimbola descried Ejigbomekun as Ejigbo, omo ekun (Ejigbo, the child of the Tiger), a town called Ejigbo". ${ }^{35}$ Whereas, it is a market in Ilé-Ifẹ which had its origin in primordial time. At the same time, the aboriginal inhabitants of Ejigbo also have their origin traced to Ilé-Ifẹ..$^{36}$ According to oral tradition, a pregnant woman from Ejjigbo town who was a regular attendant of the market fell in labor in the market, she gave birth to a boy and that was how the market adopted the name Ejigbomekun. ${ }^{37}$ The authenticity of this story is in doubt as it has no base in any Ifá literary corpus, Yorùbá adage, or any other tradition. A tradition has also associated Ejìgbomẹùn market with the Ugbo people who were believed to be autochthonous inhabitant of Ilé-Ifẹ̀. This has been done through the adulteration of the name of the market to become, "Igbomekun Market". However, all these have emanated from people's desperate bid to ascertain the origin of the market.

33 Oral interview with Chief Akinwande Olajire...

34 A. Salami, (2002), Ifa, A Complete Divination, Lagos: NIDD Publishing and Printing Limited, p. 53.

35 W. Abimbola, (2006), Ijinle Ohun Enu Ifa, Apa kin-in-ni, Ibadan: University Press PLC, p. 24.

36 See, B. Lasisi, (2005), Ejigbo Local Government: A Positive Reference Point and the Profiles of Prominent Indigenes, Osogbo: BIL Communications and Publishers, p.16 and "Ejigbo" Oyo State Town Series, No.2, Vol 14, p.5.

37 Baba Oja Ejigbomekun, Ile-Ife. 
In Ifa' literary corpus, the market was always referred to as E jìgbomẹkun market without any link with the duo of Ejigbo town and İgbo or Ugbo people. However, devotion of time for an exercise as this will help in no small measure to correct the feedback effect that has emanated from lack of adequate knowledge and poor documentation mentioned earlier.

In addition to the above features, Ejigbomẹkun market was the most cited in Ifá literary corpus. Although, market is often mentioned in Ifá corpus, but when it comes to the mentioning of specific markets, Ejigbomẹkun surpasses other Yorùbá markets. For example, in Ifá literary corpus, mentioned were also made of markets like Akẹsán, Òjé, among other ancient Yorùbá markets. This implies that Yorùbá people had a lot to do with Ejìgbomẹkun market. Some examples of Ifá references to the market that are pregnant with meanings included the followings:

Ogbè-òfún (Ogbèfún)

Agbé relé

Agbé ròde

Agbe gègègè rọjà Ėjigbòmẹkùn

A diá fún Owólẹléwà

Tín tọ̀run bọ wáyé

Wọ́n ní ó rúbọ

Kó le baà ríre gbogbo

Ogbebonbe ó rúbọ kèè pẹ bẹẹ ni kè jinà

Abáni bọ́lá bá peregede

Àse owó le wa ohun aya

Ëèyàn è ése fújà láilówó

Owo lẹwà ohun aya

Ile lẹwà ohun ọmo

Ėèyan è ése fuja láinílé

Ilé lẹwà ohun ọmọ. ${ }^{38}$

It was carried home

It was carried out

It was carried aloft to the market of E'jigbomẹkun

Cast divination for Owólélẹwà

That was coming to the earth from heaven

He was asked to perform sacrifice

So that he would have good things of the earth

It was not too long after he had offered sacrifice

38 A. Salami, (2002), Ifa, A Complete Divination...p.50 
He was met with plenty of good things

Therefore, money is the beauty in conjunction with wife

No one sets for showoff without having money

Wealth is the beauty in conjunction with the wife

Therefore, the house is the beauty in conjunction with children

No one sets for showoff without having a house

The house is the beauty in conjunction with children. ${ }^{39}$

In the above Ifa literary corpus, Owolewa was a masquerade that was coming into the world. When he consulted the Ifa oracle on how he could be wealthy and enjoy, the oracle advised him to always be dancing towards Ejigbomekun market where many children would follow him and people would give him money. ${ }^{40}$ Therefore, the market where very many people were in attendant was the place where all his needs would be met. This explains the reasons for masquerades attendance of markets even in the modern time and corroborates Mcintosh's claim that Yoruba traditional market was a place where attendants with diverse motives met. ${ }^{41}$ And since masquerades attendance was in line with oracle advice as seen in Owolewa's case, then markets were meeting places of humans and spiritual beings.

İrosùn Ọsá

Èkùrọ́ Oríta mẹta ni ó șẹnu șónșó șọloọkọ́

A día fún Òrúnmilà

Nijọ́ tín lọ rèé yanrí lóde İdó

Yóò sì yan ìwà lọjà Ėjigbòmẹkùn

Wọ́n ní ki baba ó rúbọ

O rúbọ

Kèè pé bẹẹ ni kèèjinnà

Abáni bọla bá peregede

Èlà nikan ló ní wà rere

Àwọn tó yanrí ò ní wà lọ́wọ́

Elà nìkan ló ní wà rere. ${ }^{42}$

Èkùrọ́ Oríta mệta ni ó șẹnu șóńṣó sộlộkọ̣

Cast divination for Ọ̀únmi là

On the day he was going to choose his destiny in the ancient city of İdó

39 Ibid.

40 Oral interview with Abiodun Ifagbenro on 15th October 2019, an Ifa Priest in Telemu Osun State, 62 years.

41 M. K. Mcintosh, 2009, Yoruba Women, Work, and Social Change...p. 66.

42 A. Salami, (2002), A Complete Divination...p.242. 
And he would choose character in Ejìgbòmẹkùn market

He was asked to perform sacrifice

He performed sacrifice

It was not too long when he became much favored

It is Ela alone that has good character

Those who chose head has no character

It is Ela alone that has good character. ${ }^{43}$

The import of the above Ifa literary corpus is that, it is not enough to have good fortune, good characters are equally important if one would have peace and enjoy in this world. One is expected to learn how to comport oneself in the market of the world where we meet people with diverse behaviors. For example, in the market of the world, people will love and hate you, many will quarrel with you and teach you many things. According to the literary corpus, it is from the diverse people in the market of the world that one choses good character as demonstrated by Orunmila.

Òtúrúpọn Ọsẹe (Òtúrúpọ̀nsẹ)

Òrúpa-jẹgẹ́dẹ-awo-ẹbá-ọnà

A día fún Ató

Níọttí ń șòwò rọjà Ėjigbòmẹkùn

$N$ lo rèé pónko

Wọ́n ní kó fi aṣo àdìre àrà rẹ rúbọ nítorí ikú

Ogbebonbe ó rúbo

Kè pẹ bẹee ni kè jinnà

Aba ni láikú kàngiri

Àikú kàngiri là ń báni lẹ́sẹ Ọba òrị̀à

Òrúpa-jẹ́gẹdeẹ-awo-ẹbá-ọ̀nà

Casts divination for Ató

On the day she was trading to E'jigbòmẹkun market

She was going to sell pap

She was asked to perform sacrifice with the àdire cloth on her in order to avert death

She performed sacrifice

It was not too long

She was met with longevity of life

The type that the deities can secure for their worshipers (Salami 2002: 669).

43 Ibid, p. 243. 
This Ifa corpus confirms the fact that market is a meeting point of the human and spirit. Ato was asked to offer her adire cloth (the cloth she normally wear in the market) as a sacrifice because her spiritual being was coming to visit her in the market. The cloth that was demanded from her for sacrifice was the only thing that her heavenly visitor had to identify her. However, she was spared of the untimely death, having been obedient and offered sacrifice. $^{44}$

\section{Ėjì Ogbè}

Ọdá owo awo koro

Aabo obinrin re

Omọ wọn òkè İjerò

Bí ọdá owó ti ń dá mi

Bẹé ni ààbò mi ń bò mí

A díá fún Òrúnmilà

Nijọ́ tí olojò mẹta ó wọ̀ sílé baba

Ifá o si ni owó kan áà yọ ná

Ni Òrúnmi là bá pe Ààbò obinrin è

Pé kí o ko àwọn nkan iní òhun lọ sọjà Ėjìgbòmẹkùn lọ tà

İợké tí Òrúnmi là rà ní ègbèje

Nwộn șeé ní ogóje

İrộké tó rà ní ẹgbẹfà

Nwọ́n șeé ní ogộ́à

Iboriifá re ẹgbẹrìndínlógún

Nwộn șeé ni ọkànlélógún

Ni ààbò bá mẹ́kún ó fi dígbe

Ó fi iyẹerẹ șohùn arò

Ó ní awo oja náà ò pójú owó

Ni Òrúnmi là bá fi iyẹreè dáa lóhun

Pé kí ó ta awọn ojà náa bẹẹ beẹe

Ni Ààbò bá ta ojà náà ní itàkutà

Ló bá mówó ra oúnje wálé

Awọn olojò mẹ́ta náà, Ikú, Àrun àti Eșù jẹun wọ́n sì yó. ${ }^{45}$

Òdá owó awokóró

Ààbò obinrin rè

Omọ wọn òkè İjerò

As I am getting broken

44 Ibid.

45 W. Abimbola, (2006), Ijinle Ohun Enu Ifa, ... pp.20-21. 
So is my covering taking care

Cast for Ộrúnmi là

When three owners of the days visited him

And he has no money for entertainment

The, he called Aabo his wife

And ordered her to take his belongings to market for sale

Iroke that Ộrúnmi là purchased with one thousand four hundred

Was priced at one hundred and forty

Iruke that he purchased with one thousand two hundred

Was priced at one twenty

The cover of his Ifá that he purchased with three thousand two hundred

Was priced at twenty-one

This made Ààbò to burst into tears

And she began to communicate with his husband in iyẹerẹ voice, that the items

were poorly priced

Òrúnmi là, her husband also replied her with ìẹerẹ voice that she should sell them

at any price

Ààbò then sold the items and used the proceed to buy food items

The three owners of the days, Ikú, Àrun and Eșu then ate to their satisfaction and

spared the entire household. ${ }^{46}$

This Ifa corpus teaches that the choice of life and death lays in one's hand and that the choice of life is always accompanied with a high cost. The fact that people were aware of the cost of the divination wares of Orunmila before they priced them down abnormally is a reference to market as a place to choose character. Thus, Orunmila pursued life at all cost. Death that was looming sequel to the unwanted visitors he had was eventually averted.

Ọyệkú Méji

Awuruku mọdágbàá

Oduduruku ni wọnrọnrọn niwọnrọnrọn

Àwọn ọmọdé kéékèèkée darí jọ

Nwọn paya ikú nigbe lọjà Ėjìgbòmẹkùn

Nitorí apopo ori ẹran

Ikú gbọ ikú han bí gate

Ikú moka șe kesé, o mere șokunfà

46 Ibid. 
O fa kekee pa kese ija mese danindanindanin

Ikú tẹ orí Igbá, Igbá gbiramunle

Ikú tẹ orí apa, apá gbiramunle

Ikú te orí oro, orí gbiramunle

Esisi agbala n lotutu legbo

Ewe won ló kona firifiri

A dia fun Ayunre ti n sọmọ ikẹhin wọn léńjeléńje

Wọ́n ní korubọ láikú ara rẹ

Ogbẹ́bọ $n$ be orubo

Ikú to lóhun o paYunre o le paYunre mo

Ikú wa yo teere o fige sale, o wa fariwo ta sááleșáále

Ayunre ni mo jawe oluyeere o, oyeye

Mo jáwé oluyeere o, oyeye. ${ }^{47}$

Awurukumodagbaa

Odudurukuniwọnrọnrọniwọnrọnrọn

Children gathered

And cause Iku's mother to weep in Ejjigbòmẹkù market

Because of the head of a goat

Ikú heard and cried like gate

Ikú harmed himself with Ọká and Erè

And scorpion was added to them

Ikú got to Igbá tree and killed it

Ikú got to Apá tree and killed it

Ikú got to O'ro tree and killed it

Essisi plant had a fresh root

But has hot leaves

Cast divination for Ayunrẹ tree who happened to be the youngest of them all

He was asked to perform sacrifice so as to avert death

He obeyed

Death could no longer kill Ayùnrẹ again

Ikú striped and fell down and hit the ground with his chest, he cried out in agony

Ayunrẹ́ said I plucked oluyeere leaves to avert death

I plucked oluyeere leaves to avert death

The above Ifa verse is also a confirmation of Ejigbomekun market serving as a meeting point of the heaven and the earth. Such that evidence of the

47 W. Abimbola, (2006), Ijinle Ohun Enu Ifa, pp. 26-27 
attendance of the gods and antigods abound. For example, Iku is an antigod. This is absolutely mythical, and the mentioning of tree names as humans is proverbial, all confirming the spirituality of the market in the ancient time. However, since there were two sessions, oja taye and oja torun, the deeper meaning belongs to those who can discern the things of the spirit.

Òdí Méji

Ó dúró, nípẹkun òpópó

Ó bẹrẹ nípệkun òpópó

Okoti Bababa ni n be nípẹkun òpópó

A día fún Òșùwọ̀n

Tín lọ sọ́jà Ėjìgbòmẹkùn

Wọ́n ní kó rúbọ kó lè baà níyi

Ogbebonbe ó rúbọ

Igba to dọjà ni wọn ba $n$ faa láfàgbà

Ijó ni jó, ayọ ní ń yọ

Oń yin àwọn awo, àwọn awo ń yinfá

Ó ya ẹnu kókó orin awo kó síi lẹ́nu

Ó $n$ tootoo gbẹde lawo

Osunwon tooto lo gbedelawo. ${ }^{48}$

He stood at the end of a street

He stooped at the end of a street

Okoti Babaaba is at the end of the street

Cast divination Òșùwọ̀n

That was going to Ejigbomẹkun market

He was asked to perform sacrifice in order to have value

He obeyed

When he got to the market everybody wanted him

He was dancing and rejoicing

He was praising the Ifá priests and the priests were in turn praising Ifá

He opened his mouth and began to sing the priests' songs

He said, it is true, you are well versed as a priest

Òṣùọ̣n, it is true, you are well versed as a priest. ${ }^{49}$

Òșùọ̣n (measurement) in the above Ifa corpus was and is very popular in the market. At the same time Òșùọ̣n is a common feature of the market. But this Ifa verse is attributing its popularity to its obedience exhibited with

48 W. Abimbola, (2006), Ijinle Ohun Enu Ifa, ... p. 52

49 Ibid. 
respect to the sacrifice it had made right from the primordial time. The fact that modern Òsùwọ̀n is not human implies that there is a deeper meaning that Abimbola tagged the use of personification in Ifa explanation. ${ }^{50}$

Moreover, Idin-Iwori is another Ifa corpus that confirms the primordial Ejigbomẹkun as a market for the heaven and earth. In this corpus, also, was the evidence of the dead attendance of Ejigbomekun market to transact business with the living. It is also a place where other spiritual beings attended to transact businesses with man. For example, in Idin-Wori, there was a record of a fairy who came to Ejigbomekun market. The beauty of this spiritual being who was a woman endeared a man to her. The man was also in the market to sell his merchandise (hoes) in the Ifá corpus below.

Idin-Wori (Odi Iwori)

İdingbàgbà iwòrìgbàgbà,

Iworigbagba mo lorunaladodo

Aládodo Iwó

Adikaraọ̣ọo kalẹ

A día fún oloko tín ns șwo rọjà Ẻ jigbòmẹkùn

Wọ́n ní kó rúbo. kó lè baa ríre gbogbo

Ogbebonbe ó rúbo

Ebọ ló rú bẹé ni kò sài kilọ

Kèè pẹ bẹe ni kè jinnà

Eyinorifaawokintinse. $^{51}$

İdíngbàgbà ìwòrìgbàgbà,

İwòrìgbàgbà mon lorun aladodo

Aladodo Iwo

Adikaraọ̣ọó kalẹ

Cast divination for Olộkọ that was going to sell in Ẻjìgbòmẹkù market He was asked to perform sacrifice

He performed sacrifice

But he failed to heed warning

It was not too long after

The words of the priests came to pass

As stated in the above Ifá corpus, the man was warned to mind his business in the market in addition to the sacrifice he had offered. It was his inability to heed the warning that caused problem for him. As soon as he sold

50 W. Abimola, (1976), Ifa, An Exposition of Literary Corpus ... p. 105.

51 Oral interview with Chief Aiodun Ifagenro. 
all his merchandise, he saw a woman whose beauty made him to forget the warning given to him at home. However, he proposed to the woman, thinking she was human. The woman told him that she could not marry him, but he insisted and when people were leaving for their individual homes after the day's transactions, he followed the woman who was warning him to return home. When they left the vicinity of the town, the woman began to warn the man in a song as follow.

Olọ́kọ́ sìn, ọlọkộ sin lẹ́hin mi o

$\sin n$ o sin

Bóò bá sin ookan ò doolóyún

$\sin n$ o sin

Bóò bá sin ookan ò do ẹlẹjẹ,

$\sin n$ o $\sin$

Bóò bá sin oo dájùlé ọ̀run o

$\sin n o \sin .^{52}$

Olộkọ́ return, please return from me

Return, no I will not

If you don't return you will get to River Olóyún

Return, no I will not

If you don't return, you will get to the river of blood

Return, no I will not

If you don't return, you will get to heaven

Return, no I will not

As the woman said in the song, they got to River Oloyún, got to the River of Blood after which they got to the abode of the woman. At the place, the woman commanded the ground to open. And as the woman jumped into it, Olọ́kọ followed him. Thus, he went to a journey of no return.

Also, it was a market for the gods and the anti-gods. Records of the attendance of the market by the gods such as Ifá, Ògún, Șàngó, Òșun, Oya etc. were common place in Ifá literary corpus. In E ji ogbè, E’jigbòmẹu market was also a world market as it drew its attendants from all over the world. An important principle of the market was that, attendants dare not look at faces of other attendants too much, because, one could see a dead person or a spiritual being and the consequence of this was dangerous as inherent in IdinWori above. ${ }^{53}$

52 Ibid.

53 . Ib id. 


\section{Conclusion}

Ėjigbòmẹkùn market typifies Yorùbá cosmology. Thus, the Yorùbá belief of the world division into spiritual and physical, and the interactions of the inhabitants of the two divisions is well depicted in the examination of Ejigbòmẹun market. It was a market of the Yorùbá world, simply because, it was attended by the humans, the gods, anti-gods and other spiritual beings. The modern Ejigbomẹkun market was the continuation of the primordial market in name only, as various features attributable to the primordial one are no longer in place. For example, the night session is no longer holding and the modern market is just a human market. However, in the course of our research, we were made to know that nothing has changed about the market as it is being implied here, because all the attributes of the primordial Ejigbomẹun market are intact in the modern one, but they can only be seen or perceived by those who have access to the power of the primordial people. For example, the people of the period could see what natural eyes could not see and they could communicate with the spiritual forces. Thus, they were superhuman. The difference between us and them therefore account for the difference between the primordial and modern Èjìgbòmẹkùn market. 